Yu.M. Vaskovskyi, O.A. Geraskin

\title{
TURBOGENERATOR ROTOR HEATING IN PRESENCE OF ROTOR WINDING DEFECTS AND EXCITATION CURRENT FORCING
}

Purpose. Research of the TGV-200 turbogenerator rotor heating in case of rotor winding damages, which occur as a result of prolonged operation of the turbogenerator, namely - clogging of the ventilation channels of the rotor winding and the occurrence of short circuits of the rotor windings. Particular attention is paid to heating during short-term increasing of the excitation current, which is performed to keep the generator in synchronous mode of operation. Methods. Field mathematical models are used. Results. It is determined that the clogging of the rotor winding ducts has a greater effect on the rotor heating compared to the short circuits of the individual windings of the rotor winding. It was defined that increasing of the excitation current within the limits regulated by the current standards of the turbogenerators operation becomes impossible with clogging of a small number of ventilation channels of the rotor winding, which impairs the efficiency of the turbogenerator and requires its output to repair. Scientific novelty. A mathematical model of rotor heating is developed in case of typical damages of the rotor winding. Practical value. The areas in the rotor where the temperatures and temperature gradients reach the highest values was determined, which allows to recommend the locations of the optimal temperature sensors placements. References 10 , figures 11. Key words: turbogenerator, rotor winding, temperature, temperature gradient, short circuit, clogging of cooling channels, excitation forcing.

Мета. Дослідження нагріву ротора турбогенератора типу ТГВ-200 за наявності ушкоджень обмотки ротора, які виникають внаслідок тривалої експлуатації турбогенератора, а саме - засмічення (закупорка) вентиляційних каналів обмотки ротора і виникнення коротких замикань витків обмотки ротора. Особлива увага приділяється нагріву при короткочасному форсуванні струму збудження, яке виконується для утримання генератора в синхронному режсимі роботи. Методика. Використовуються польові математичні моделі. Результати. Визначено, цио засмічення вентиляційних каналів обмотки ротора в більшій мірі впливає на нагрів ротора у порівнянні з коротким замиканням окремих витків обмотки ротора. Встановлено, що форсування струму збудження в межсах, які регламентовані діючими стандартами експлуатації турбогенераторів, стає неможлливим при засміченні невеликої кількості вентиляційних каналів обмотки ротора, що погіриує ефективність роботи турбогенератора і потребує його виводу в ремонт. Наукова новизна. Розроблено математичну модель нагріву ротора при наявності типових ушкоджень обмотки ротора. Практичне значення. Визначено ділянки в роторі, де температури і температурні градієнти досягають найбільших значень, що дозволяе рекомендувати місця оптимального розташування датчиків температури. Бібл. 10 , рис. 11.

Ключові слова: турбогенератор, обмотка ротора, температура, градієнт температури, коротке замикання, засмічення охолоджуючих каналів, форсування збудження.

Цель. Исследование нагрева ротора турбогенератора типа ТГВ-200 при наличии повреждений обмотки ротора, которые возникают в результате длительной эксплуатации турбогенератора, а именно - засорение (закупорка) вентиляционных каналов обмотки ротора и возникновения коротких замыканий витков обмотки ротора. Основное внимание уделяется нагреву при кратковременном форсировании тока возбуждения, которое выполняется для удержания генератора в синхронном режиме работы. Методика. Используются полевые математические модели. Результаты. Установлено, что засорение вентиляционных каналов обмотки ротора в большей степени влияет на нагрев ротора по сравнению с коротким замыканием отдельных витков обмотки ротора. Установлено, что форсирование тока возбуждения в пределах, которые регламентированы действующими стандартами эксплуатации турбогенераторов, становится невозможным при засорении небольшого количества вентиляционных каналов обмотки ротора, что ухудиает эффективность работы турбогенератора и требует его вывода в ремонт. Научная новизна. Разработана математическая модель нагрева ротора при наличии типовых повреждений обмотки ротора. Практическое значение. Определены участки в роторе, где температуры и температурные градиенты достигают наибольших значений, что позволяет рекомендовать места оптимального расположения датчиков температуры. Библ. 10, рис. 11.

Ключевые слова: турбогенератор, обмотка ротора, температура, градиент температуры, короткое замыкание, засорение охлаждающих каналов, форсирование возбуждения.

Introduction. The reliability of the turbogenerator (TG) largely determines the reliability of the power plant as a whole. Unforeseen damage of TG leads to significant economic losses, and therefore ensuring the reliable operation of power units of the power plant and, in particular, TG remains an urgent scientific and technical task. Its relevance is especially increasing recently due to the aging of the existing TG park.

The reliability of the TG depends largely on the heating of the structural parts of its design, and in particular the design of the rotor. During the operation of a proper TG, significant overheating of the rotor can occur for various reasons: prolonged operation of the TG in asynchronous or asymmetric modes, long-term forcing of the excitation current, etc. Such overheating is predictable and is taken into account in the calculations when designing TG. However, in the process of long-term operation of the $\mathrm{TG}$, the gradual degradation of the structure causes damage that causes unacceptable overheating. Thus, significant unacceptable overheating of the rotor winding (RW) occurs in case of disturbances in the cooling system, damage of the electrical insulation of the winding and turn's short circuits, etc. Short circuits (C) Yu.M. Vaskovskyi, O.A. Geraskin 
of the winding turns of the TG may occur as a result of overheating or gradual mechanical grinding of the insulation of the turns when the temperature extensions vary over time. Significant overheating of the RW occurs as a result of overlapping of the ventilation ducts of the RW turns due to their clogging (dirt appearance) or due to the displacement of insulating gaskets between the turns at the TG starts and stops. Particularly critical is overheating when the excitation current is forced to flow in the damaged RW.

In order to avoid significant economic losses due to the damage to the RW to replace the planned and preventive repairs, repairs are made according to the results of the assessment of the actual technical condition, based on the utilization of systems of control and monitoring of the technical condition of the TG rotor elements, including the temperature sensors. Modern methods of non-destructive testing of the thermal state of the TG rotor involve the use of control equipment for heating of electrical equipment with the use of various measurement methods based on the fixation of readings of: thermometer, ohmmeter, thermocouple and the level of infrared radiation. Real-time monitoring and analysis of heating of the TG rotor elements is performed with the help of temperature sensors embedded in different TG points during its production.

To improve the efficiency of intellectual control of the thermal condition of the rotor, the results of mathematical modelling of its heating in different modes of operation of TG and different variants of damage to the RW are required. The study of the temperature field in TG was carried out in [1-10]. In particular, [1] investigated the effect of clogging of the cooling channels of the RW on the temperature field and local overheating of the TG rotor, which depend on the number of clogged channels of the RW. These studies were conducted at the nominal value of the excitation current. But, as already noted, unacceptable heating of the RW occurs during the forcing of the excitation current, which in order to keep the TG in synchronism at the occurrence of short circuits in the network is temporarily performed by the excitation system. The combination of the effects of these two factors - the presence of RW clogged cooling channels and forcing the excitation current leads to unacceptable overheating of the RW even with a small number of clogged channels. The possible presence of shortcircuited (SC) turns of the RW also influences on this. Studies in this formulation of the problem have not been conducted so far, but the relevance of such consideration is increasing in view of the reduction of the residual life of the powerful TGs currently being used at Ukrainian power plants.

The goal of the work is the investigation of the temperature state of the TG rotor in the appearance of typical damage of the RW: the presence of clogged cooling channels of the RW turns and a short circuit of the part of the RW turns, both in the rated mode of operation of the TG, and at forcing its excitation current.

Object of study. For the study of the temperature field the turbogenerator TGV-200 of power of $200 \mathrm{MW}$ with hydrogen cooling was selected, having the following parameters: the outer diameter of the rotor barrel
$D_{R}=1.075 \mathrm{~m}$, the length of the rotor barrel $L_{R}=5.1 \mathrm{~m}$, the number of slots/ tooth division of the rotor $Z_{2} / Z_{\mathrm{Z}}=36 / 52$, the rotor rotation speed $n=3000 \mathrm{rpm}$, the excitation voltage $U_{f}=440 \mathrm{~V}$, the nominal value of power factor $\cos \varphi_{n}=0.85$ (over-excitation), the heat resistance class of rotor winding insulation $-\mathrm{F}\left(155^{\circ} \mathrm{C}\right)$.

The thermal conductivity of the materials of the TG rotor were taken as follows: a) the equivalent thermal conductivity of the slot insulation of the rotor winding (taking into account the presence of small gaps between the insulation and the slot walls) $\lambda_{i s}=0.25 \mathrm{~W} /\left(\mathrm{m} \cdot{ }^{\circ} \mathrm{C}\right)$; b) the thermal conductivity of the duralumin wedges of the rotor $\lambda_{0}=155 \mathrm{~W} /\left(\mathrm{m} \cdot{ }^{\circ} \mathrm{C}\right)$; c) the thermal conductivity of copper conductors of the RW $\lambda_{C u}=400 \mathrm{~W} /\left(\mathrm{m}^{\circ}{ }^{\circ} \mathrm{C}\right)[4]$.

The coefficients of heat transfer from different design surfaces of the rotor to the cooling medium $\alpha$ have different numerical values for different surfaces, namely for the outer surface of the rotor barrel, the surfaces of the ventilation channels in the copper conductors of the RW. The following numerical values of the coefficients of heat transfer between these surfaces and hydrogen were adopted [1, 4]: a) the coefficient of heat transfer between the outer surface of the rotor barrel and cooling hydrogen $\alpha=1100 \mathrm{~W} /\left(\mathrm{m}^{2} \cdot{ }^{\circ} \mathrm{C}\right)$; b) the coefficient of heat transfer between copper conductors of turns and hydrogen in ventilation ducts of the RW $\alpha_{v}=450 \mathrm{~W} /\left(\mathrm{m}^{2} \cdot{ }^{\circ} \mathrm{C}\right)$.

The mathematical model of the $\mathrm{TG}$ rotor temperature field in steady-state modes is based on the stationary differential equation of thermal conductivity, which in Cartesian coordinates in $2 \mathrm{D}$ formulation has the following form [4]:

$$
\lambda\left[\frac{\partial^{2} \theta(x, y)}{\partial x^{2}}+\frac{\partial^{2} \theta(x, y)}{\partial y^{2}}\right]=Q(x, y),
$$

where $\theta(x, y)$ is the unknown temperature distribution function; $\lambda$ is the thermal conductivity; $Q(x, y)$ are the volumetric specific heat field sources, $\mathrm{W} / \mathrm{m}^{3}$ which are the power losses in the elements of the TG rotor when operating in the nominal synchronous mode and during the excitation. In particular, the following sources of heat dissipation were taken into account: a) Joule power losses in copper of the RW $Q_{R W}=i_{R W}^{2} \cdot r_{R W}$, where $i_{R W}$ and $r_{R W}$ are the current and active resistance of the RW, respectively; b) the ventilation losses on the rotor surface during its rotation, which were determined by known formulas in the TG design manuals.

On the outer surface of the rotor and on the inner surfaces of the ventilation channels of the rotor winding boundary conditions of the third kind were set:

$$
\lambda \frac{\partial \theta}{\partial n}=-\alpha\left(\theta-\theta_{M}\right)
$$

where $\alpha$ is the above coefficient of heat transfer; $\theta_{M}$ is the temperature of the cooling refrigerant (hydrogen). The average hydrogen temperature was assumed to be $\theta_{M}=45^{\circ} \mathrm{C}$ with regard to its heating during the passage of long ventilation ducts of the RW turns.

The found stationary temperature distribution is used as the initial temperature distribution in solving the problem of transient thermal conductivity in the modes of 
forcing the excitation current, which is described by the following equation [4]:

$$
\lambda\left[\frac{\partial^{2} \theta(x, y, t)}{\partial x^{2}}+\frac{\partial^{2} \theta(x, y, t)}{\partial y^{2}}\right]-c \rho \frac{\partial \theta(x, y, t)}{\partial t}=-Q(x, y, t),
$$

where $Q(x, y, t)$ are the volumetric specific power losses for the problem of transient thermal conductivity, $\mathrm{W} / \mathrm{m}^{3}$; $c$ is the heat capacity, $\rho$ is the specific density of the material, $t$ is the time. Equation (3) is solved together with conditions (2).

Modelling of damage of the RW has been carried out as follows. With a short circuit of the turns of the RW, the specific losses in SC turns are zero due to the lack of excitation current in them. The presence of clogged ventilation ducts in the RW turns was modelled by the absence of heat transfer from the inner surface of the ventilation ducts: the heat transfer coefficient between the turns' conductors in the rotor slot and the clogged ventilation duct was assumed $\alpha_{v}=0$.

Results of investigations. For the purpose of comparative analysis, the results of simulation and study of the temperature field in the rotor with different technical condition and operating mode of the TG are presented below.

1. Heating of the intact rotor in the nominal TG operation mode. The simulation results are obtained in Comsol Multiphysics 5.4 and reflect the TG rotor temperature field in nominal mode. The picture of the field is shown in Fig. 1.

According to the results of the analysis we can draw the following conclusions:

1. The maximum RW copper temperature is observed in the slots of the rotor, which are located around the $q$ axis of the rotor. In particular, the maximum conductor temperature is $87.2{ }^{\circ} \mathrm{C}$ and is observed in the 3rd OR turn from the bottom of the slot which is located near the $q$ axis.

2. The highest heating in the TG rotor steel is observed in the middle teeth on the $q$ axis and in the rotor yoke. Figure 2 shows the temperature distribution in the rotor steel along the diameter along the $q$ and $d$ axes.

3 . The least heated are duralumin wedges and large rotor teeth $\left(45.3{ }^{\circ} \mathrm{C}\right)$, which is conditioned by their cooling conditions.

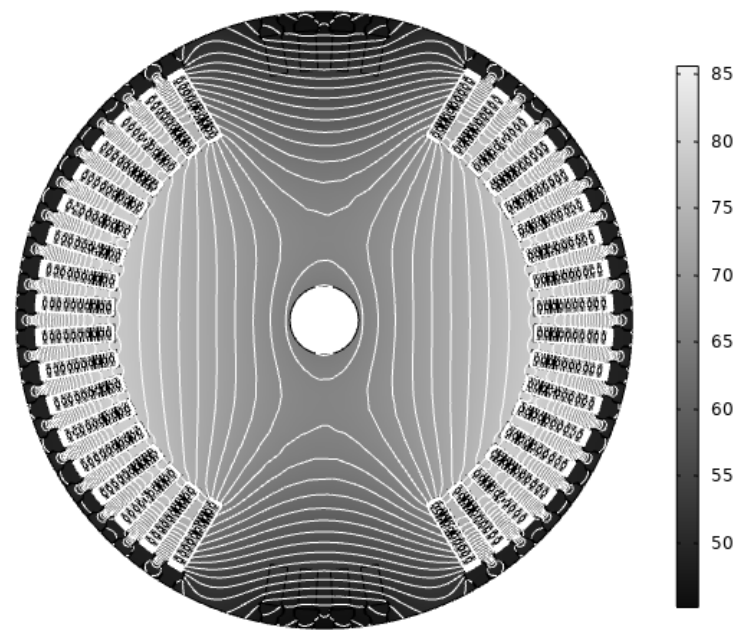

Fig. 1. Temperature distribution in the rotor of the intact TG

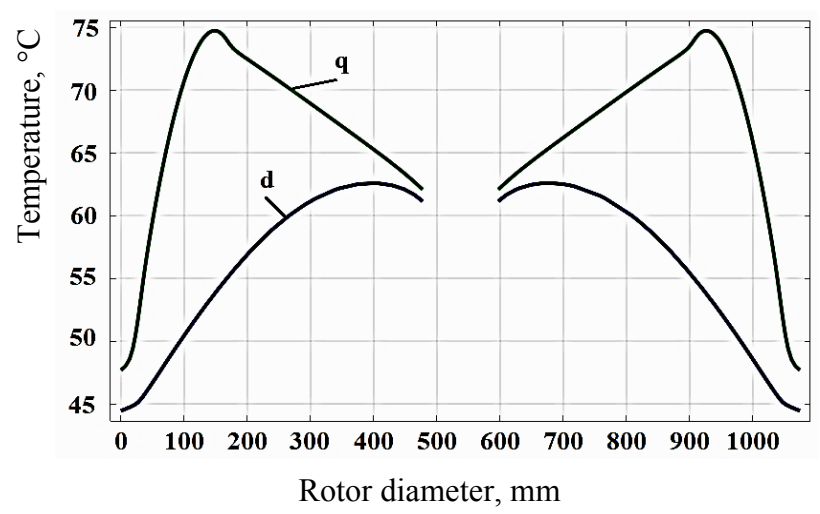

Fig. 2. Temperature distribution in the rotor steel of the intact TG along the radius along the $d$ and $q$ axes

The study of the temperature gradient distribution in the TG rotor makes it possible to determine the areas where the highest thermomechanical stresses occur. It is established that:

1. Temperature gradients on the steel sections near the bottom of the slots adjacent to the large teeth are greater $\left(300{ }^{\circ} \mathrm{C} / \mathrm{m}\right)$ compared to the temperature gradients on the rotor steel sections located near the bottom of the slots around the $q$ axis $\left(126^{\circ} \mathrm{C} / \mathrm{m}\right)$.

2 . Relatively large values of temperature gradients in steel are observed at the top of the teeth near the rotor wedges $\left(565^{\circ} \mathrm{C} / \mathrm{m}\right)$.

3 . The temperature gradients in the electrical insulation of the slots reach much higher values, in particular: in the fiberglass insulation under the wedges $\left(11627^{\circ} \mathrm{C} / \mathrm{m}\right)$; in the fiberglass insulation in the base of slots $\left(9913{ }^{\circ} \mathrm{C} / \mathrm{m}\right)$; in the fiberglass insulation adjacent to the walls of the large tooth $\left(17006^{\circ} \mathrm{C} / \mathrm{m}\right)$; in the fiberglass insulation adjacent to the walls of the remaining slots $\left(18542^{\circ} \mathrm{C} / \mathrm{m}\right)$.

This is due to the fact that the RW turns are the most heated elements, and the duralumin wedges and the rotor steel are the most cooled. Therefore, when choosing a material for insulating pads under the wedge and at the base of the slot, it is advisable to give preference to materials having a lower coefficient of thermal expansion to prevent significant thermomechanical stresses.

A separate question arises when choosing the thermophysical parameters of the RW insulation of the TG. The temperature fields in the rotor were investigated when replacing the existing regular insulation of the RW, which has the thermal conductivity $\lambda_{i s}=0.25 \mathrm{~W} /\left(\mathrm{m} \cdot{ }^{\circ} \mathrm{C}\right)$, with a more thermally conductive insulation of the Micadur type with the thermal conductivity $\lambda_{i s}=0.58 \mathrm{~W} /\left(\mathrm{m}^{\circ}{ }^{\circ} \mathrm{C}\right)$, which was proposed in [2].

According to the results of numerical calculations, it was found that the temperature gradient in the fiberglass insulation adjacent to the walls of the small tooth near the $q$ axis decreased by $16.8 \%$, and in the sub-wedge laying of the slot located near the large TG tooth decreased by $36.2 \%$. But overall, the maximum temperature in the intact rotor decreased by only $1.5{ }^{\circ} \mathrm{C}(1.7 \%)$ to $85.7^{\circ} \mathrm{C}$. This result is explained by the fact that $85 \ldots 90 \%$ of the heat dissipation in the RW is transferred through the ventilation ducts in the turns and only $10 \ldots 15 \%$ of the heat dissipation passes through the insulation and is transferred from the rotor surface. 
2. Heating of the rotor with a short circuit of the RW turns. At a short circuit of a part of the turns of the RW, the excitation current bypasses the SC turns. Therefore, the electrical resistance of the RW decreases and the excitation current increases, which increases the heating of the other turns of the RW. Figure 3 shows the dependence of the RW temperature on the number of SC turns that are in the same coil in one slot of the rotor.

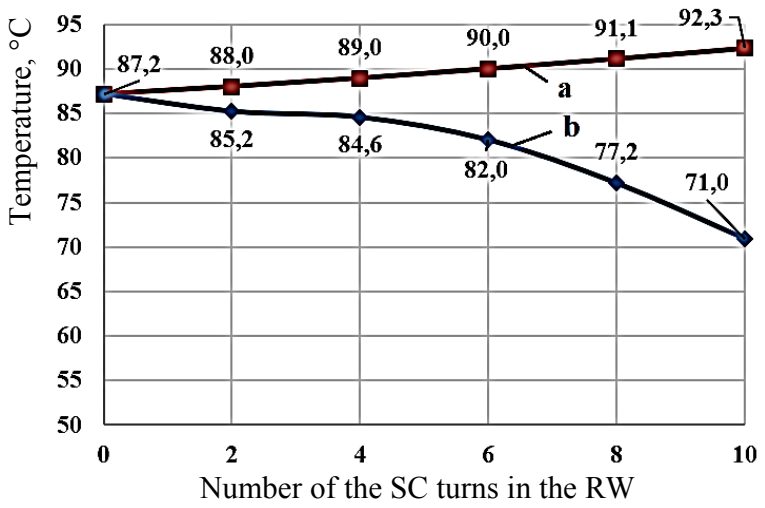

Fig. 3. Maximum temperature depending on the number of the $\mathrm{SC}$ turns in the slot of the RW: $a$ ) over the entire area of the rotor; $b$ ) in the damaged slot of the rotor on the $q$ axis of the rotor

For example, with the short circuit of all 10 turns of the RW coil located in one slot, the maximum temperature of the other turns of the RW increases by only $6 \%$ (Fig. 3,a). The temperature in the slot with SC turns is slightly reduced because the damaged turns are not loaded with current (Fig. 3,b). From Fig. 3 it can be concluded that, even with a short circuit of even 10 turns of the RW $(5.56 \%$ of the total number of turns of the $\mathrm{RW})$, the rotor heating increases slightly.

The rotor heating leads to an increase in the temperature gradient in the RW insulation of the TG (Fig. 4).

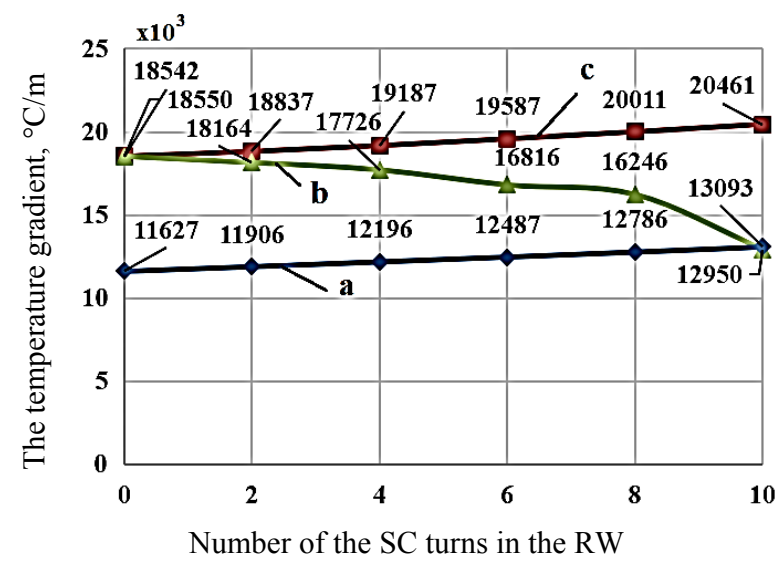

Fig. 4. Maximum value of the temperature gradient, depending on the number of the SC turns of the RW: $a$ ) in the sub-wedge laying of the slot; $b$ ) in the fiberglass insulation adjacent to the walls of the small tooth; $c$ ) throughout the rotor area

3. Rotor heating during clogging of the cooling channels of the RW turns. Figure 5 shows the maximum temperature in the RW in the presence of clogged cooling channels of the RW turns located in one slot.

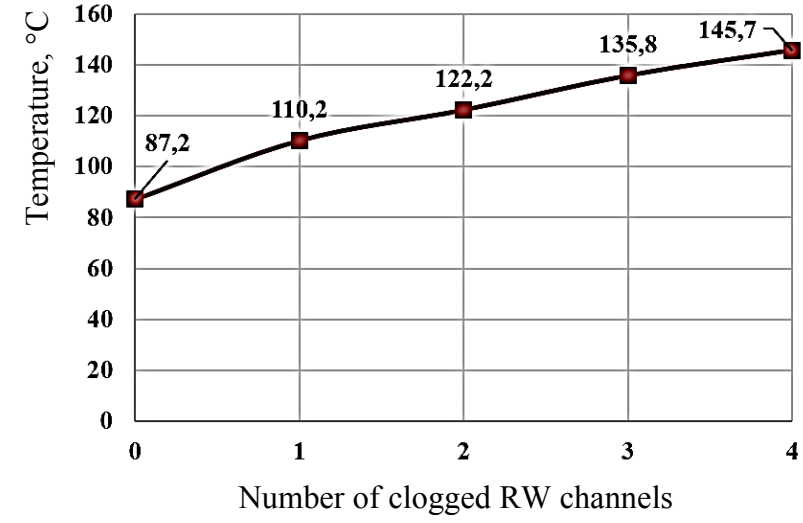

Fig. 5. Maximum temperature in the slot of the rotor depending on the number of clogged RW channels

Figure shows that when clogging in the slot of 4 of the 10 existing ventilation channels, the maximum temperature in this slot increases by $56 \%$ and approaches the critical permissible insulation temperature of class $\mathrm{F}$, and with more clogged channels it exceeds the permissible temperature. Figure 6 shows the increase of the temperature gradient in the insulation of the RW during clogging of the cooling channels. From Fig. 6 it can be seen that when the 4 channels are clogged, the temperature gradient in the insulation of the RW increases 2.2 times. Thus, unlike short circuits of turns, the clogging of their ventilation channels causes significantly dangerous overheating of the RW.

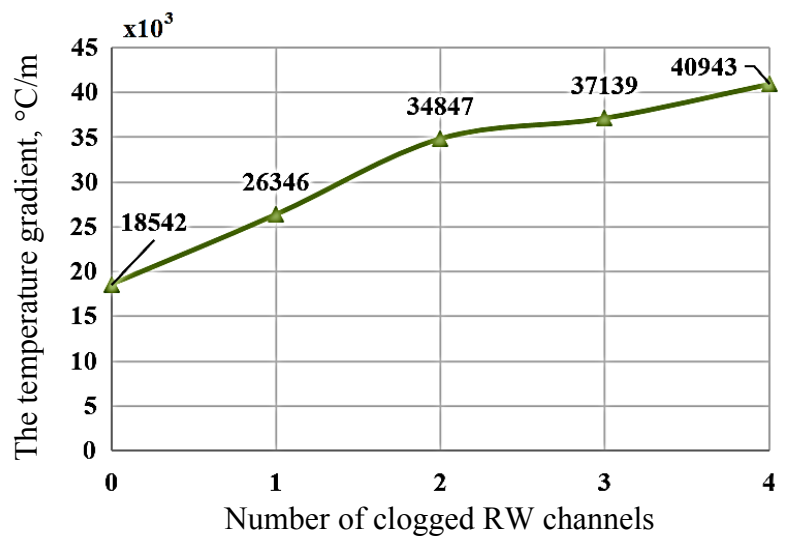

Fig. 6. Maximum value of the temperature gradient in the fiberglass insulation as a function of number of the clogged channels of the RW

4. Heating of the rotor when forcing the excitation current. In accordance with the requirements of item 4.17 of the Standard GOST 21558-2000, the direct-cooled TG excitation system must withstand a double rated excitation current for at least $20 \mathrm{~s}$. The calculated heating of the rotor during the following process of forcing the excitation current was considered: for a time of $1 \mathrm{~s}$, the excitation current according to a linear law increases from the nominal value to the forced value, which is determined by the coefficient of forcing

$$
k_{f}=\frac{i_{f f}}{i_{f n}},
$$

where $i_{f f}, i_{f n}$ are, respectively, the forced and nominal value of the excitation current (in the calculations the 
coefficient varies within $1.25 \ldots 2$ ). For a further 19 seconds, the forced current value remains unchanged. The temperatures acquired by the rotor at the end of the specified forcing process are presented below.

Dependencies of maximum values of the temperature and temperature gradient in the rotor on the value of the forcing factor $k_{f}$ are shown, respectively, in Fig. 7, 8. For comparison, Fig. 7 also shows a line of the allowed temperature value.

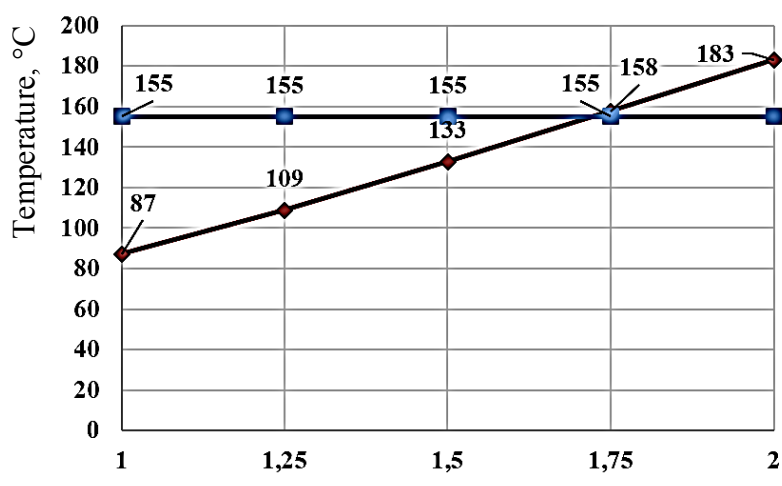

The coefficient of forcing excitation current

Fig. 7. Maximum temperature in the slot of the rotor of the intact TG, depending on the coefficient of forcing excitation current

From Fig. 7 it can be seen that already at $k_{f}=1.75$ the maximum temperature in the rotor reaches the maximum permissible value. There are also significant temperature gradients in the insulation of the RW (Fig. 8), which are 3.1 times higher than their values in the nominal mode, which makes it possible to damage the insulation of the RW not only due to overheating, but also due to significant thermomechanical deformations.

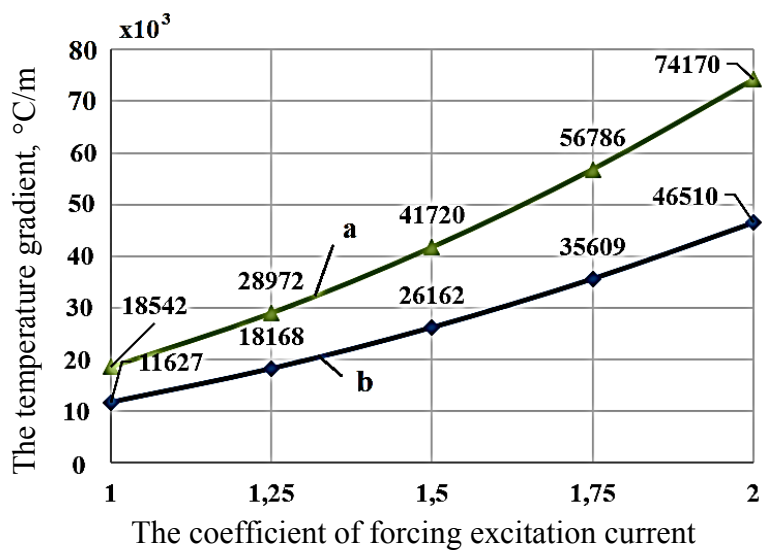

Fig. 8. Maximum values of the temperature gradient depending on the coefficient $k_{f}$ :

a) in the fiberglass slot insulation;

b) under the wedge insulation

5. Heating of the rotor during clogging of the ventilation channels of the $R W$, forcing of the excitation current and short circuits of the RW turns. It is unacceptable to heat in the case of forcing the excitation current if the RW contains the damage discussed above. Figure 9 depicts the temperature dependence of the forcing coefficient of the excitation current of at the different number of the SC turns of the
RW and in the absence of clogged ventilation channels. Figure 10 shows the dependence of the rotor temperature on the coefficient of forcing the excitation current at the different number of clogged ventilation channels (varies from 0 to 3) and in the absence of the SC turns of the RW. In Fig. 9, 10, the lower graph corresponds to the intact rotor, and as the number of damaged turns increases, the graphs pass higher. From Fig. 9 it is shown to what extent, depending on the number of the SC turns the admissible value of the coefficient $k_{f}$ decreases.

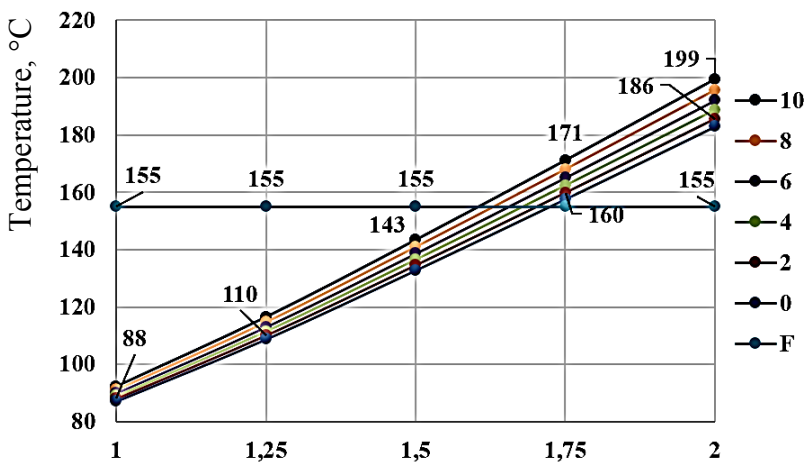

The coefficient of forcing excitation current, p.u.

Fig. 9. Maximum temperature in the TG rotor, depending on the coefficient of forcing of the excitation current and the different number of the SC turns of the RW (in the absence of clogged channels)

From Fig. 10 it can be seen that when the 3 channels are clogged when the excitation current is forced twice, the maximum temperature rises to $337{ }^{\circ} \mathrm{C}$, which is unacceptable. Thus, damage of the cooling system of the RW during the clogging of the ventilation channels significantly affects the possibility of forcing the excitation current, provided that the permissible heating of the RW is maintained. Regulated forcing becomes impossible, since even at the 1st clogged channel, the allowed $k_{f}$ value is only 1.35 , which does not meet the requirements of the existing TG operating standards.

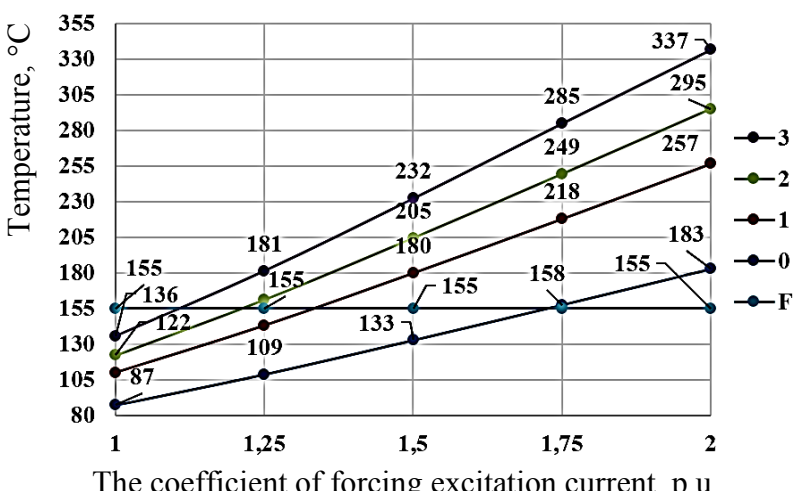

Fig. 10. Maximum temperature in the TG rotor, depending on the $k_{f}$ coefficient with different number of clogged channels and the absence of the SC turns of the RW

Figure 11 depicts similar dependencies for one of the probable variants of combined damage: at one clogged channel and at two SC turns of the RW in forcing excitation. From Fig. 11 it can be seen that such combined damage is also dangerous for the TG. 


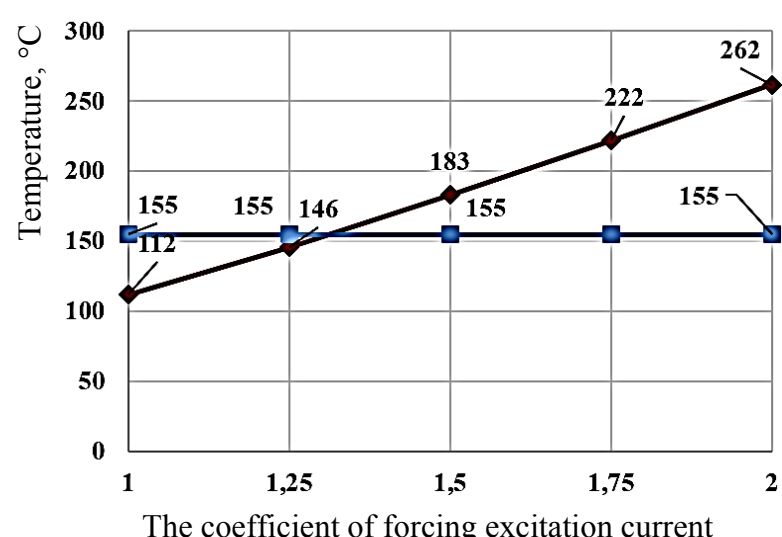

Fig. 11. Maximum temperature in the rotor at one clogged channel and at two SC turns of the RW depending on the coefficient of forcing of the excitation current

Conclusions.

1. In the long-term operation of powerful $\mathrm{TG}$, in the RW damages occur - clogging (blocking) of the ventilation channels and short circuits of the RW turns, as a result of which the heating of the RW is substantially increased both in the steady rated mode of operation, and, especially, when the excitation current is forced in dynamic modes.

2. Ventilation ducts clogging is particularly dangerous. Even with one clogged channel, the continuous forcing of the excitation current can occur with coefficient of not more than 1.4 (or it is necessary to significantly reduce the forcing time), and for 3 or more clogged channels the forcing becomes practically impossible and the TG needs to be removed for repair. Therefore, it is important to develop reliable methods and tools for diagnosing and timely elimination of clogging of the ventilation channelsof the RW turns of the TG.

3. Areas with the highest values of the temperature and temperature gradient are determined, which allows to reasonably place temperature sensors.

\section{REFERENCES}

1. Kuchinskiy K.A. Analysis of the temperature field of the of $300 \mathrm{MW}$ turbogenerator rotor with asymmetry in the cooling of the slot zone. Technical electrodynamics, 2013, vol.4, pp. 59-66. (Rus).

2. Fedorenko G.M., Kolesnik G.A. High-voltage insulation system with increased thermal conductivity for turbogenerators.
Works of institute of electrodynamics National Academy of Sciences of Ukraine, 2010, no.25, pp. 38-41. (Rus).

3. Fedorenko H.M., Vaskovskyi Yu.M., Saratov V.O. Temperature distribution in the rotor in case of excitation current forcing in the Q-winding of the modernizing TGV-300 turbogenerator. News of power engineering, 1998, no.4, pp. 33-39. (Ukr).

4. Filippov I.V. Teploobmen $v$ electrisnyh masynah [Heat transfer in electric machines]. Leningrad, Energoizdat Publ., 1986. 256 p. (Rus).

5. Shulzhenko N.G., Gontarovsky P.P., Protasova T.V. Influence of non-uniformity of heat dissipation in the generator rotor on its thermal stress state. Aerospace Engineering and Technology, 2007, no.8(44), pp. 135-139.(Rus).

6. Lu Y., Li W., Ma X., Jin H.Y. Numerical simulation of temperature field in rotor of large turbogenerator with aircoolant. Proceedings of the Chinese Society of Electrical Engineering, 2007, vol.27, no.12, pp. 7-13.

7. Weili L., Xuefeng Y., Debao G., Yongli F. Calculation and analysis of fluid flow and heat transfer of air cooled turbogenerator with multipath ventilation. Transactions of China Electrotechnical Society, 2009, vol.24, no.12, pp. 24-31.

8. Singh A.N., Doorsamy W., Cronje W. Thermographical analysis of turbogenerator rotor. Electric Power Systems Research, 2018, vol.163, pp. 252-260. doi: 10.1016/j.epsr.2018.06.019.

9. Irwanto B., Eckert L., Prothmann T. Thermal unbalance behaviour of turbogenerator rotors. Proceedings of the 9th IFToMM International Conference on Rotor Dynamics. Springer, Cham, 2015, pp. 2231-2242. doi: 10.1007/978-3-31906590-8 183.

10. Weili L., Chunwei G., Ping Z. Calculation of a complex 3-D model of a turbogenerator with end region regarding electrical losses, cooling, and heating. IEEE Transactions on Energy Conversion, 2011, vol.26, no.4, pp. 1073-1080. doi: 10.1109/tec.2011.2161610.

Received 11.11.2019

Yu.M. Vaskovskyi ${ }^{1}$, Doctor of Technical Science, Professor, O.A. Geraskin ${ }^{1}$, Candidate of Technical Science, Associate Professor,

${ }^{1}$ National Technical University of Ukraine «Igor Sikorsky Kyiv Polytechnic Institute»,

37, Prospect Peremohy, Kyiv-56, 03056, Ukraine, e-mail: vun157@gmail.com

How to cite this article:

Vaskovskyi Yu.M., Geraskin O.A. Turbogenerator rotor heating in presence of rotor winding defects and excitation current forcing. Electrical engineering \& electromechanics, 2020, no.1, pp. 10-15. doi: 10.20998/2074272X.2020.1.02. 